九州大学学術情報リポジトリ

Kyushu University Institutional Repository

\title{
Effects of Dietary Zinc Levels on Zinc, Iron and Copper Content in Tissues of the White Leghorn Cockerels
}

\section{Eltohamy, Magda Mohammed}

Laboratory of Animal Husbandry II, Faculty of Agriculture, Kyushu University

Takahara, Hitoshi

Laboratory of Animal Husbandry II, Faculty of Agriculture, Kyushu University

Okamoto, Masao

Laboratory of Animal Husbandry II, Faculty of Agriculture, Kyushu University

https://doi.org/10.5109/23696

出版情報: 九州大学大学院農学研究院紀要. 24 (2/3)，pp.65-74，1979-11. Kyushu University バージョン：

権利関係 : 
J. Fac. Agr., Kyushu Univ., 24(2•3), 65-74 (1979)

\title{
Effects of Dietary Zinc Levels on Zinc, Iron and Copper Content in Tissues of the White Leghorn Cockerels
}

\author{
Magda Mohammed Eltohamy, Hitoshi Takahara \\ and Masao Okamoto
}

Laboratory of Animal Husbandry II, Faculty of Agriculture, Kyushu University 46-06, Fukuoka 812

(Received May 17. 1979)

\begin{abstract}
An experiment was conducted with one day-old White Leghorn male chicks to study the effects of different levels of dietary $\mathrm{Zn}$ on the concentration of $\mathrm{Zn}$. Fe and $\mathrm{Cu}$ in different organs. Regression analysis revealed positive correlation between dietary $\mathrm{Zn}$ concentration and $\mathrm{Zn}$ concentration in the liver and pancreas until 50 days of age and in the testes and kidneys until 40 days. There was negative correlation between dietary $\mathrm{Zn}$ concentration and tissue $\mathrm{Zn}$ at duration of feeding in the testes with all dietary $\mathrm{Zn}$ levels and in the pancreas with the two higher levels of $\mathrm{Zn}$. Zn concentration in the heart, brain, breast muscle and leg muscle was not influenced by addition of $\mathrm{Zn}$ to the diet. The antagonistic effect of $\mathrm{Zn}$ with $\mathrm{Fe}$ contents was observed at 40.50 and 85 days of age in the liver. The same effect was detected at 50 and 85 days in the testes and kidneys. In the spleen and heart, accompanying the increase in the dietary $Z n$, decreases in $\mathrm{Fe}$ concentration were evident at 30 and 50 days. No significant changes were found in $\mathrm{Fe}$ concentration in the brain and muscles throughout the experimental period. The lack of a loss of Fe concentration in these organs suggests that a critical level of $\mathrm{Zn}$ was not attained to affect $\mathrm{Fe}$ concentration. The $\mathrm{Cu}$ concentration in the liver, kidneys, heart and brain was not affected by addition of $\mathrm{Zn}$ to the diet and by duration of feeding.
\end{abstract}

\section{INTRODUCTION}

Adaptation to environmental alteration and the capacity of self regulation are fundamental characteristics of living systems which result in the maintenance of a dynamic steady state called homeostasis. A basic requirement in maintaining homeostasis is the ability to alter the rate of metabolic reactions which underlie the various physiological processes. $\mathrm{Zn}$ homeostasis has been established in rats and ruminants. (Stake et al., 1973, 1975; Ansari et al., 1976). Information relating to regulation may be obtained by investigating the role of different levels of $\mathrm{Zn}$ in the maintenance of homeostasis (Miller et al., 1970; Stake et al., 1975). In ruminants, Zn homeostasis is effective with low dietary $\mathrm{Zn}$ but less effective with the high $\mathrm{Zn}$ level.

The interactions of $\mathrm{Zn}$ with other dietary constituents are important especially in the study of $\mathrm{Zn}$. It appears that no particular symptom may be specifically attributed to $\mathrm{Zn}$ alone, but some changes are observed as a result of several other nutrients. Smith and Larson (1946) indicated that the micro. 
cytic anemia caused by feeding a relatively high concentration of $\mathrm{Zn}$ in rats was actually the result of impaired utilization of Fe for hemoglobin formation and this condition was corrected by addition of $\mathrm{Cu}$ to the diet. Later, Settlemire and Matrone (1967) suggested that $\mathrm{Zn}$ affected Fe metabolism by; a) impairing the incorporation of $\mathrm{Fe}$ into or release from ferritin, which would influence Fe absorption and storage, and b) shortening the life span of eryth. rocytes, which would cause a faster turnover of Fe. Van Campen and Scalfe (1967) postulated that $\mathrm{Zn}$ alters $\mathrm{Cu}$ metabolism by impairing its absorption as mediated primarily via the direct effect of $\mathrm{Zn}$ either in or on the intestine, when rats received $\mathrm{Zn}$ either intraduodenally or intraperitoneally.

Excess dietary $\mathrm{Zn}$ has been documented to produce an antagonism to $\mathrm{Fe}$, $\mathrm{Cu}$ and $\mathrm{Ca}$ in rats (Cox and Harris, 1960). But this effect is not completely understood in the fowl.

The present study was therefore undertaken to investigate the effects of dietary $\mathrm{Zn}$ levels on the concentration of $\mathrm{Zn}, \mathrm{Fe}$ and $\mathrm{Cu}$ in different organs.

\section{MATERIALS AND METHODS}

The experiment was conducted with one day-old White Leghorn cockerels randomly divided into 4 groups, one control and three experimental groups, of 30 chicks each. The control group was fed the basal diet described previously (Eltohamy et al., 1979) containing $32 \mathrm{ppm} \mathrm{Zn,} 85 \mathrm{ppm}$ Fe and $5 \mathrm{ppm} \mathrm{Cu}$. Three groups were given the experimental diets which 50, 250 and $1000 \mathrm{ppm} \mathrm{Zn}$ (as $\mathrm{Zn}$ ammonium sulphate) were added to the basal diet respectively. The experimental period was 85 days. The diet and distilled water were offered $a d$ libitum. Five chicks from each group were killed at 10,20,30,40, 50 and 85 days of age. The liver, testes, pancreas, kidneys, heart, spleen, brain, breast muscle and leg muscle were removed rapidly, and the individual organs from each chick were stored separately at $-20^{\circ} \mathrm{C}$ until required for analysis.

The tissues were wet-digested with a $3: 1(\mathrm{v} / \mathrm{v})$ mixture of nitric and perchloric acids and then assayed by atomic absorption spectrophotometry for $\mathrm{Zn}, \mathrm{Fe}$ and $\mathrm{Cu}$ determination. $\mathrm{Zn}, \mathrm{Fe}$ and $\mathrm{Cu}$ content were calculated as $\mathrm{Zn}$, $\mathrm{Fe}$ and $\mathrm{Cu}$ concentration (ppm) on fresh weight basis. The results were analysed statistically by analysis of variance and linear regression correlation (Snedecor, 1956). The standard error of the mean was given.

\section{RESULTS}

Data showing the effects of different levels of dietary $\mathrm{Zn}$ on the concentration of $\mathrm{Zn}, \mathrm{Fe}$ and $\mathrm{Cu}$ in selected organs are presented in Tables 1, 2 and 3. At 10 days of age, the concentration of $\mathrm{Zn}$ in the liver, pancreas, testes, kidneys and spleen of cockerels fed 1000 ppm dietary Zn was significantly higher than those fed the basal control diet. There was a significant increase in the concentration of $\mathrm{Zn}$ in the liver and spleen of cockerels fed $250 \mathrm{ppm}$ dietary $\mathrm{Zn}$ compared with those from the control group. But the apparent increase 
Table 1. Effect of dietary $\mathrm{Zn}$ levels on $\mathrm{Zn}$ concentration of selected organs.

\begin{tabular}{|c|c|c|c|c|c|c|c|}
\hline \multirow{2}{*}{ Tissue } & \multirow{2}{*}{$\left|\begin{array}{c}\mathrm{Zn} \\
\text { added. } \\
\text { to the: } \\
\text { diet } \\
(\mathrm{ppm})\end{array}\right|$} & \multicolumn{6}{|c|}{ Tissue $\mathrm{Zn}$ concentration at the experimental period } \\
\hline & & $\begin{array}{c}10 \\
(\mathrm{pl}\end{array}$ & $\begin{array}{c}20 \text { days } \\
(\mathrm{ppm})\end{array}$ & $\begin{array}{c}30 \text { days } \\
(\mathrm{ppm})\end{array}$ & $\begin{array}{c}40 \text { days } \\
(\mathrm{ppm})\end{array}$ & $\begin{array}{c}50 \text { days } \\
(\mathrm{ppm})\end{array}$ & \\
\hline ive & $\begin{array}{r}0 \\
50 \\
250 \\
1000\end{array}$ & $\begin{array}{l}3.92 \\
7.1^{11} \\
28.4^{1)}\end{array}$ & $\begin{array}{l}2.4 \pm 7.51 \\
29.6 \pm 2.5 \\
36.0 \pm 10.9^{1)}\end{array}$ & $\begin{array}{l} \pm 12.1 * 21 . \\
2 \pm 1.0 " 2 \\
9.0 \pm 2.4 " \\
1.8 \pm 3.4^{11}\end{array}$ & $\begin{array}{l}6 \pm 4.2 \% \\
3.8 \pm 1.82, \\
24.5 \pm 2.3 \\
44.71-24.21\end{array}$ & $\begin{array}{r}20.7 \pm 1.3^{*} 27 \\
24.4-\mathrm{t} 4.6^{\prime \prime} \\
22.4 \pm 3.42 \\
28.1 \pm 4.3^{3}\end{array}$ & $\begin{array}{c}3 \pm 4.5 " \\
32.2 \pm 4.3 \\
28.1 \pm 9.9 \\
36.4 \pm 5.3\end{array}$ \\
\hline $\mathrm{an}$ & $\begin{array}{r}\mathbf{0} \\
50 \\
250 \\
1000\end{array}$ & $\begin{array}{r}28 . \\
47 . \\
53 . \\
110 .\end{array}$ & 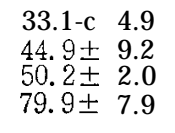 & $\begin{array}{l}24.7 \pm 8.5 \\
39.1 \pm 5.5 \\
47.6 \pm 3.0^{2} \\
78.6 \pm 2.72\end{array}$ & $\begin{array}{l}19.2 \pm 1.3 \\
34.8 \pm 3.82 \\
29.8 \pm 3.9^{2} \\
49.9 \pm 12.0^{2)}\end{array}$ & $\begin{array}{l}15.9,2.6 \\
23.6 \pm 6.92 \\
25.4 \pm 2.8 \\
43.4 \pm 11.4^{11}\end{array}$ & $\begin{array}{l}24.9 \pm 5.4 \\
40.6 \pm 0.81 \\
15.3 \pm 1.0 " \\
21.8 \pm 4.5\end{array}$ \\
\hline es & $\begin{array}{r}0 \\
50 \\
250 \\
1000\end{array}$ & $\begin{array}{r}83.3 \\
144.7 \\
210.4 \\
306.6\end{array}$ & $\begin{array}{c}77.1 \pm 26.6 \\
141.3 \mathrm{i} 11.71 \\
59.8 \pm 78.0^{2)} \\
231.5 \pm 69.91\end{array}$ & $\begin{array}{l}93.1 \pm 60.6 \\
7 . \quad 1137.2 \\
00.8 \pm 47.4\end{array}$ & $\begin{array}{l}35.8 \pm 7.4 \\
32.3 \pm 5.7 \\
35.1 \pm 12.5 \\
45.1 \pm 18.53\end{array}$ & $\begin{array}{l}24.2 \pm 7.6 \\
33.5 \pm 9.4 \\
38.3 \pm 17.1 \\
42.6 \pm 25.9^{11}\end{array}$ & $\begin{array}{c}13.4 \pm 1.6 \\
13.6 \pm 0.5 \\
6.5 \pm 0.2^{1)} \\
6.2 \pm 0.6^{2}\end{array}$ \\
\hline idr & $\begin{array}{r}\mathbf{0} \\
50 \\
250 \\
1000\end{array}$ & $\begin{array}{l}6.5 \\
=6.5 \\
2.82\end{array}$ & $\begin{array}{l}19.6 \pm 2.3 \\
20.6 \pm 2.0 \\
25.3 \pm 1.7\end{array}$ & $\begin{array}{l}19.4 \pm 3.4 \\
21.2 \pm 1.22 \\
22.7 \pm 1.5 ” \\
28.4 \pm 4.8\end{array}$ & $\begin{array}{l}18.7 \pm 5.7 \\
22.9 \pm 0.5^{1} \\
22.6 \pm 2.5 \\
28.7 \pm 4.6\end{array}$ & $\begin{array}{l}17.1 \pm 2.4 \\
20.3 \pm 1.8 \\
19.1 \pm 1.5 \\
21.7 \pm 2.4\end{array}$ & $\begin{array}{l}19.4 \pm 1.2 \\
23.9 \pm 1.9 \\
23.1 \pm 2.2 \\
23.5 \pm 1.1\end{array}$ \\
\hline le & $\begin{array}{r}0 \\
50 \\
250 \\
1000\end{array}$ & $\begin{array}{l}.5 \\
1^{11} \\
9^{2)}\end{array}$ & $\begin{array}{l}35.9 \pm 9.3 \\
36.2 \pm 6.2 \\
42.0112 .5 \\
48.7 \pm 15.0\end{array}$ & $\begin{array}{l}25.1 \pm 3.9 \\
25.9 \pm 2.2 \\
28.8 \pm 2.9 \\
28.6 \pm 3.4\end{array}$ & $\begin{array}{l}24.7 \pm 3.9 \\
29.6 \pm 4.3 \\
30.5 \pm 0.1 \\
32.6 \pm 6.0\end{array}$ & $\begin{array}{l}20.4 \pm 0.9 \\
25.2 \pm 2.32 \\
21.9 \pm 1.5 \\
22.5 \pm 0.9\end{array}$ & $\begin{array}{l}22.7 \pm 0.7 \\
22.5 \pm 0.7 \\
22.4 \pm 0.7 \\
20.7 \pm 0.8\end{array}$ \\
\hline 1 & $\begin{array}{r}0 \\
50 \\
250 \\
1000\end{array}$ & $\begin{array}{l}10.9 \\
13.2 \\
5.3 \\
8.8\end{array}$ & $\begin{array}{l}25.8 \pm 3.5 \\
26.2 \pm 3.4 \\
27.2 \pm 2.5 \\
26.414 .1\end{array}$ & $\begin{array}{l}24.5 \pm 2.2 \\
24.5 \pm 1.5 \\
26.4 \pm 1.8 \\
27.3 \pm 1.5\end{array}$ & $\begin{array}{l}24.2 \pm 1.7 \\
25.6 \pm 1.2 \\
24.2 \pm 5.8 \\
24.1 \pm 0.9\end{array}$ & $\begin{array}{l}24.1 \pm 1.8 \\
24.8 \pm 0.9 \\
23.8 \pm 2.3 \\
24.2 \pm 2.0\end{array}$ & $\begin{array}{l}25.9 \pm 0.8 \\
25.0,3.8 \\
25.0 \pm 1.5 \\
24.4 \pm 1.1\end{array}$ \\
\hline rain & $\begin{array}{r}\mathbf{0} \\
50 \\
250 \\
1000\end{array}$ & $\begin{array}{l}11.1 \pm 1.4 \\
11.9 \pm 1.3 \\
12 . \mathrm{a}+3.0 \\
13.0 \pm 1.6\end{array}$ & $\begin{array}{l}11.7 \pm 0.6 \\
14.5 \pm 1.7 \\
13.2 \pm 0.4 \\
13.2 \pm 2.7\end{array}$ & $\begin{array}{l}11.3 \pm 0.5 \\
11.5 \pm 0.8 \\
11.3 \pm 1.1 \\
12.9 \pm 0.6\end{array}$ & $\begin{array}{l}12.6 \pm 2.0 \\
12.0 \pm 2.0 \\
13.9 \pm 2.8 \\
12.3 \pm 0.8\end{array}$ & $\begin{array}{r}8.8 \pm 1.4 \\
10.3 \pm 0.6 \\
9.8 \pm 0.7 \\
10.5 \pm 0.7\end{array}$ & $\begin{array}{l}10.1 \pm 1.2 \\
10.4 \pm 0.6 \\
12.0 \pm 1.2 \\
11.6 \pm 2.6\end{array}$ \\
\hline $\mathrm{st}_{1}$ & $\begin{array}{r}0 \\
50 \\
250 \\
1000 \\
\end{array}$ & $\begin{array}{l}11.7 \pm 3.4 \\
11.4 \pm 0.8 \\
16.0 \pm 4.2 \\
18.5 \pm 3.5\end{array}$ & $\begin{array}{ll}7.6 \pm & 0.9 \\
7.8 \pm & 0.9 \\
7.8 \pm & 0.9 \\
8.41 & 0.7\end{array}$ & $\begin{array}{ll} \pm & 0.7 \\
\pm & 0.4 \\
\pm & 0.3 \\
\pm & 0.6\end{array}$ & $\begin{array}{l}4.6 \pm 0.2 \\
4.9 \pm 0.6 \\
5.3 \pm 0.6 \\
5.4 \pm 1.2\end{array}$ & $\begin{array}{l}4.8,0.5 \\
5.5 \pm 0.9 \\
5.8 \pm 2.1 \\
4.8 \pm 0.4\end{array}$ & $\begin{array}{l}4.8 \pm 0.2 \\
5.8 \pm 0.9 \\
5.3 \pm 0.6 \\
5.6 \pm 1.6\end{array}$ \\
\hline us & $\begin{array}{r}0 \\
50 \\
250 \\
1000\end{array}$ & $\begin{array}{l}24.0 \pm 6.8 \\
24.8 \pm 9.7 \\
25.4 \pm 3.5\end{array}$ & $\begin{array}{ll}18.0-\mathrm{t} & 1.8 \\
18.6 \pm & 2.8 \\
19.4 \pm & 2.4 \\
20.4 \pm & 3.5\end{array}$ & $\begin{array}{l}15.1 \pm 2.8 \\
16.8 \pm 2.5 \\
16.4 \pm 1.1\end{array}$ & $\begin{array}{l}13.7 \pm 1.6 \\
14.8 \pm 2.9 \\
14.7, \quad 1.4\end{array}$ & $\begin{array}{l}13.6 \pm 2.0 \\
21.7 \pm 4.5 \\
12.8 \pm 2.9 \\
11.1 \pm 1.8\end{array}$ & $\begin{array}{r}14.2 \pm 3.5 \\
10.9 \pm 0.8 \\
9.9 \pm 1.4 \\
15.9 \pm 3.1\end{array}$ \\
\hline
\end{tabular}

* Mean value\&standard error. 1) Significantly different $(\mathrm{p}<0.01)$ from control
group by analysis of variance. 2) Significantly different $(\mathrm{p}<0.05)$ from control group by analysis of variance.

in the concentration of $\mathrm{Zn}$ in the other organs, when 250 and $50 \mathrm{ppm}$ dietary $\mathrm{Zn}$ was fed, was not statistically significant. Though $\mathrm{Zn}$ concentration was reduced in the heart with the dietary $\mathrm{Zn}$ levels, the reduction was not statistically significant.

The data indicated that increasing levels of dietary $\mathrm{Zn}$ were associated 
Table 2. Effect of dietary $\mathrm{Zn}$ levels on $\mathrm{Fe}$ concentration of selected organs.

\begin{tabular}{|c|c|c|c|c|c|c|c|}
\hline \multirow[b]{2}{*}{ Tissue } & \multirow{2}{*}{$\begin{array}{c}\mathrm{Zn} \\
\text { added } \\
\text { to the } \\
\text { diet } \\
(\mathrm{ppm})\end{array} \mid$} & \multicolumn{5}{|c|}{ Tissue $\mathrm{Fe}$ concentration at the experimental period } & \multirow[b]{2}{*}{$\begin{array}{c}85 \text { days } \\
(\mathrm{ppm})\end{array}$} \\
\hline & & $\begin{array}{c}10 \text { days } \\
(\mathrm{ppm})\end{array}$ & $\begin{array}{c}20 \text { days } \\
(\mathrm{ppm})\end{array}$ & $\begin{array}{c}30 \text { days } \\
(\mathrm{ppm})\end{array}$ & $\begin{array}{c}40 \text { days } \\
(\mathrm{ppm})\end{array}$ & $\begin{array}{c}50 \text { days } \\
(\mathrm{ppm})\end{array}$ & \\
\hline Liver & $\begin{array}{r}0 \\
50 \\
250 \\
1000\end{array}$ & $\begin{array}{l}56.2 \pm 10.5 * \\
73.216 .1 \\
60.3 \pm 19.4 \\
79.91-19.2\end{array}$ & $\begin{array}{l}43.2 \pm 8.1 * \\
43.0 \pm 6.4 \\
43.2 \pm 4.2 \\
52.4 \pm 7.6\end{array}$ & $\begin{array}{c}50 . \pm 13.9^{*} \\
61.4 \pm 13.7 \\
74.5 \pm 16.5 \\
74.8 \mathrm{tt} 10.6\end{array}$ & $\begin{array}{l}+17.0^{*} \\
\mathbf{1 0 . 1} \\
+20.2 \\
\pm 10.8\end{array}$ & $\begin{array}{l}97.3 \pm \\
90.3 \\
67.1\end{array}$ & $\begin{array}{l}23.3^{*} \\
=33.1 \\
=21.0 \\
39 . a\end{array}$ \\
\hline Pancreas & $\left|\begin{array}{r}0 \\
50 \\
250 \\
1000\end{array}\right|$ & $\begin{array}{l}\text { 3. } 2 \\
3.5 \\
13.9^{11}\end{array}$ & $\begin{array}{l}14.3 \pm 1.7 \\
13.3 \pm 1.9 \\
13.6 \pm 1.2 \\
12.0 \pm 2.8\end{array}$ & $\begin{array}{ll}31 & 1.8 \\
6 \pm 1.7 \\
3 \pm & 2.1 \\
9 \pm & 1.7\end{array}$ & $\begin{array}{l}10.4 \pm 2.1 \\
10.7-\mathrm{c} 0.9 \\
11.5 \pm 3.3 \\
10.6 \pm 1.3\end{array}$ & $\begin{array}{l}11.7 \pm 2.1 \\
13.0 \pm 0.6 \\
11.9 \pm 1.9 \\
10.3 \pm 1.1\end{array}$ & $\begin{array}{r}10.1 \pm 1.1 \\
9.5 \pm 2.0 \\
8.6 \pm 1.1 \\
9.1 \pm 0.8\end{array}$ \\
\hline Testes & $\begin{array}{r}0 \\
50 \\
250 \\
1000\end{array}$ & $\begin{array}{l}5.3 \\
8.4 \\
2.8 \\
20.6\end{array}$ & $\begin{array}{l}15.7 \pm 6.3 \\
34.7111 .7 \\
38.6 \pm 5.9 \\
43.7 \pm 9.9\end{array}$ & $\begin{array}{l}14.0 \pm 0.5- \\
20.0 \pm 0.4 \\
22.4 \pm 0.8 \\
23.4 \pm 1.3\end{array}$ & $\begin{array}{l}14.1 \pm 4.1 \\
19.1 \pm 4.3 \\
19 . \text { Of } 2.7 \\
19.0 \pm 5.8\end{array}$ & $\begin{array}{c}11.5 \pm 1.9 \\
9.8 \pm 1.4 \\
8.4 \pm 0.6^{2)} \\
7.7 \pm 0.87\end{array}$ & $\begin{array}{l}6.9 \pm 0.5 \\
4.2 \pm 1.0 \\
4.7 \pm 0.8 \\
5.7 \pm 0.4\end{array}$ \\
\hline Kidneys & $\begin{array}{r}0 \\
50 \\
250 \\
1000\end{array}$ & $\begin{array}{l}5 \pm 5.0 \\
3 \pm 7.4 \\
3 \pm 8.4 \\
4 \pm 5.0\end{array}$ & $\begin{array}{l}39.8 \pm 5.3 \\
34.9 \pm 7.8 \\
36.0 \pm 3.7 \\
32.3 \pm 4.2\end{array}$ & $\begin{array}{l}48.0 \pm 8.4 \\
47.3 \pm 3.7 \\
42.7 \pm 5.9 \\
45.0 \pm 6.2\end{array}$ & $\begin{array}{l} \pm 8.9 \\
\pm 5.3 \\
\pm 6.0 \\
\pm 11.3\end{array}$ & $\begin{array}{l}47.1 \pm 5.1 \\
56.3 \pm 8.9 \\
53.0 \pm 5.1 \\
42.013 .9\end{array}$ & $\begin{array}{l}73.2 \\
79.7 \\
70.7 \\
67.0\end{array}$ \\
\hline Spleen & $\begin{array}{r}0 \\
50 \\
250 \\
1000\end{array}$ & $\begin{array}{c}52.8 \pm 8.4 \\
71.9-\mathrm{t} 6.6 \\
80.1 \pm 18.2 \\
101.3 \pm 20.9^{2}\end{array}$ & $\begin{array}{l}66.1111 .9 \\
69.5 \pm 5.1 \\
67.9 \pm 9.9 \\
71.2 \pm 11.6\end{array}$ & & $\begin{array}{l}71.7 \pm 8.7 \\
88.1 \pm 15.1 \\
68.3 \pm 9.7 \\
72.3 \mathrm{k} 15.1\end{array}$ & $\begin{array}{l}114.6 \pm 10.7 \\
109.3 \pm 12.7 \\
103.6 \mathrm{f} 23.6 \\
102.4 \pm 24.1\end{array}$ & $\begin{array}{l}.5 \\
2.5 \\
2.9 \\
.8\end{array}$ \\
\hline Heart & $\begin{array}{r}0 \\
50 \\
250 \\
1000\end{array}$ & $\begin{array}{l}32.1 \pm 3.1 \\
35 . \text { Of } 2.2 \\
36.2 \pm 5.2 \\
38.8 \pm 6.8\end{array}$ & $\begin{array}{l}34.9 \pm 3.1 \\
34.9 \pm 3.0 \\
34.2 \pm 2.7 \\
34.5 \pm 2.7\end{array}$ & $\begin{array}{l}37.7 \pm 2.1 \\
33.0 \pm 4.6 \\
38.2 \pm 4.0 \\
31.2 \pm 2.9\end{array}$ & $\begin{array}{l}31.4 \pm 2.4 \\
35.3 \pm 2.5 \\
31.8 \pm 3.6 \\
32.1 \pm 3.2\end{array}$ & $\begin{array}{l}45.8 \pm 6.6 \\
41.5 \pm 6.8 \\
37.9 \pm 3.0 \\
34.9 \pm 2.03\end{array}$ & $\begin{array}{l}39.1 \pm 2.3 \\
39.3 \pm 4.1 \\
38.3 \pm 4.2 \\
38.5 \pm 2.8\end{array}$ \\
\hline Brain & $\begin{array}{r}0 \\
50 \\
250 \\
1000\end{array}$ & $\begin{array}{l}11.3 \pm 0.9 \\
11.3 \pm 1.8 \\
11.6 \pm 1.4 \\
14.2 \pm 1.6\end{array}$ & $\begin{array}{ll}13.0, & 0.9 \\
13.0 \pm 0.8 \\
13.0 \pm 0.8 \\
11.7 \pm 1.8\end{array}$ & $\begin{array}{l}10.4 \pm 2.3 \\
11.2 \pm 1.5 \\
14.0 \pm 1.2 \\
13.6 \pm 1.5\end{array}$ & $\begin{array}{l}10.4 \pm 1.0 \\
10.0 \pm 0.6 \\
10.9 \pm 0.9 \\
14.9 \pm 0.6\end{array}$ & $\begin{array}{ll}13.3 \pm & 0.1 \\
15.8 \pm & 0.1 \\
14.0 \pm & 1.9 \\
14.9 \pm & 0.6\end{array}$ & $\begin{array}{l}14.1 \pm 0.7 \\
13.8 \pm 0.5 \\
14.1 \pm 1.2 \\
13.8 \pm 0.8\end{array}$ \\
\hline ase & $\begin{array}{r}0 \\
50 \\
250 \\
1000\end{array}$ & $\begin{array}{r}9.7 \pm 3.9 \\
11.212 .6 \\
12.3 \pm 2.8 \\
15.0 \pm 6.7\end{array}$ & $\begin{array}{l}6.0 \pm 0.9 \\
5.2 \pm 0.4 \\
5.4,0.5 \\
6.0 \pm 0.8\end{array}$ & $\begin{array}{l}4.7 \pm 1.0 \\
4.7 \pm 0.5\end{array}$ & $\begin{array}{l}4.9 \pm 0.3 \\
4.2 \pm 0.1 \\
5.0 \pm 0.3 \\
4.6 \pm 0.2\end{array}$ & $\begin{array}{l}5.9 \pm 0.5 \\
5.2 \pm 0.3 \\
6.5 \pm 0.4 \\
5.8 \pm 0.9\end{array}$ & $\begin{array}{l}3.8 \pm 0.7 \\
4.6-f \\
3.9 \pm 0.9 \\
3.9 \pm 0.9\end{array}$ \\
\hline $\begin{array}{l}\text { Leg } \\
\text { muscle }\end{array}$ & $\begin{array}{r}0 \\
50 \\
250 \\
1000\end{array}$ & $\begin{array}{l}12.2 \pm 2.1 \\
12.6 \pm 4.3 \\
12.6 \pm 2.1 \\
17.3 \pm 3.5\end{array}$ & $\begin{array}{l}12.5 \pm 1.2 \\
11.5 \pm 1.2 \\
10.8 \pm 1.4 \\
12.3 \pm 1.0\end{array}$ & $\begin{aligned} 9.2 \pm & 0.8 \\
9.4 \pm & 1.5 \\
10.7 \pm & 0.5\end{aligned}$ & $\begin{array}{rr}7.8 \pm & 0.8 \\
13.6, & 1.7 \\
8.7 \pm & 0.5 \\
9.8 \pm & 1.6\end{array}$ & $\begin{array}{ll}8.5 \pm & 0.3 \\
8.5, & 0.2 \\
7.7 \pm 0.2 \\
8.9 \pm 0.6\end{array}$ & $\begin{array}{ll}9.1 \pm & 0.9 \\
7.9 & 0.7 \\
6.4 \pm & 0.5 \\
8.8 \pm & 1.7\end{array}$ \\
\hline
\end{tabular}

* Mean valueistandard error. 1) Significantly different $(\mathrm{p}<0.01)$ from control group by analysis of variance. 2) Significantly different $(p<0.05)$ from control grouv by analysis of variance.

with increases in the concentration of $\mathrm{Zn}$ in the liver, pancreas, testes, kidneys and spleen at 10, 20, 30, 40 and 50 days of age (Table 1). At 85 days of age, no significant differences in the concentration of $\mathrm{Zn}$ in the liver were found between groups. In the pancreas, $\mathrm{Zn}$ concentration was declined with the levels of 1000 and $250 \mathrm{ppm}$ dietary $\mathrm{Zn}$ at the same age. The reduction of 
Table 3. Effect of dietary $\mathrm{Zn}$ levels on $\mathrm{Cu}$ concentration in liver, kidneys, heart and brain.

\begin{tabular}{|c|c|c|c|c|c|c|c|}
\hline \multirow[b]{2}{*}{ Tissue } & \multirow{2}{*}{$\begin{array}{l}\mid \begin{array}{c}\mathrm{Zn} \\
\text { adrar } \\
\text { togthe }\end{array} \\
\text { (ppm) }\end{array}$} & \multicolumn{6}{|c|}{ Tissue $\mathrm{Cu}$ concentration at the experimental period } \\
\hline & & $\begin{array}{c}10 \text { days } \\
\text { (ppm) }\end{array}$ & $\begin{array}{c}20 \text { days } \\
\text { (ppm) }\end{array}$ & $\begin{array}{c}30 \text { days } \\
\text { (ppm) }\end{array}$ & $\begin{array}{c}40 \text { days } \\
\text { (ppm) }\end{array}$ & $\begin{array}{c}50 \text { days } \\
(\mathrm{ppm})\end{array}$ & $\begin{array}{c}85 \text { days } \\
\text { (ppm) }\end{array}$ \\
\hline Liver & $\begin{array}{r}0 \\
50 \\
250 \\
1000\end{array}$ & $\begin{array}{l}4.3 \pm 0.5^{*} \\
5.0 \mathrm{f} 0.9 \\
4.8 \mathrm{~F} 0.5 \\
4.7 \pm 0.9\end{array}$ & $\begin{array}{l}3.6 \pm 1.3^{*} \\
4.1 \pm 0.1 \\
3.9 \pm 0.5 \\
4.0 \pm 0.4\end{array}$ & $\begin{array}{l}3.7 \pm 1.0 * \\
4.3 \pm 0.6 \\
4.8 \pm 0.6 \\
5: 6 \pm 0.9\end{array}$ & $\begin{array}{l}3.9 \pm 0.2 * \\
4.2 \mathrm{t} 0.8 \\
4.1 \pm 0.4 \\
4.4 \pm 0.3\end{array}$ & $\begin{array}{l}3.3 \pm 0.2^{*} \\
3.4 \pm 0.5 \\
3.4 \pm 0.3 \\
3.8 \pm 0.4\end{array}$ & $\begin{array}{l}4.3 \pm 1.5^{*} \\
2.3 \pm 0.1 \\
4.2 \pm 0.4 \\
4.7 \pm 0.4\end{array}$ \\
\hline Kidneys & $\begin{array}{r}0 \\
50 \\
250 \\
1000\end{array}$ & $\begin{array}{l}\text { Traces } \\
\text { Traces } \\
\text { Traces } \\
\text { Traces }\end{array}$ & $\begin{array}{l}1.9 \pm 0.3 \\
2.0 \pm 0.1 \\
2.1 \pm 0.1 \\
2.4 \pm 0.5\end{array}$ & $\begin{array}{l}2.2 \pm 0.2 \\
2.4 \pm 0.1 \\
2.7 \pm 0.5 \\
2.4 \pm 0.4\end{array}$ & $\begin{array}{l}2.4 \pm 0.2 \\
2.8 \pm 0.1 \\
2.5 \pm 0.2 \\
2.8 \pm 0.1\end{array}$ & $\begin{array}{l}2.4 \pm 0.0 \\
2.7 \pm 0.3 \\
2.5 \pm 0.3 \\
2.6 \pm 0.4\end{array}$ & $\begin{array}{l}2.6 \pm 0.2 \\
2.6 \pm 0.2 \\
2.8 \pm 0.2 \\
3.2 \pm 0.6\end{array}$ \\
\hline Heart & $\begin{array}{r}0 \\
50 \\
250 \\
1000\end{array}$ & $\begin{array}{l}3.3 \pm 0.3 \\
4 . \text { Oil. } 0 \\
3.5 \pm 0.6 \\
3.7 \pm 1.5\end{array}$ & $\begin{array}{l}3.2 \pm 0.1 \\
3.1 \pm 0.1 \\
3.1 \pm 0.2 \\
3.2 \pm 0.1\end{array}$ & $\begin{array}{l}3.5 \pm 0.1 \\
3.6 \pm 0.2 \\
3.5-1-0.1 \\
3.9 \pm 0.2\end{array}$ & $\begin{array}{l}3.1 \pm 0.1 \\
3.4 \pm 0.2 \\
3.3 \pm 0.1 \\
3.4 \pm 0.3\end{array}$ & $\begin{array}{l}2.8 \pm 0.4 \\
2.7 \pm 0.1 \\
3.1 \pm 0.2 \\
3.3 \pm 0.2\end{array}$ & $\begin{array}{l}3.3 \pm 0.3 \\
2.8 \pm 0.8 \\
3.2 \pm 0.8 \\
3.2 \mathrm{t} 0.2\end{array}$ \\
\hline Brain & $\begin{array}{r}0 \\
50 \\
250 \\
1000\end{array}$ & $\begin{array}{l}1.8 \pm 0.9 \\
2.0 \pm 0.2 \\
1.6 \pm 0.2 .0 \pm 0.24\end{array}$ & $\begin{array}{r}2: 1.9 \pm 0.010: 2 \\
1.9 \pm 0.3 \\
2.0 \pm 0.34\end{array}$ & $\begin{array}{l}2.2 \pm 0.4 \\
2.0 \pm 0.3 \\
2.2 .0 \pm 0.30 \pm 0.4\end{array}$ & $\begin{array}{l}1.9 \pm 0.2 \\
1.8 \pm 0.3 \\
3.3 \pm 0.1 .7 \pm 0.43\end{array}$ & $\begin{array}{l}1.5 \pm 0.4 \\
1.7 \pm 0.1 \\
1.8 \pm 0.21 .9 \pm 0.2\end{array}$ & $\begin{array}{l}1.8 \pm 0.2 \\
1.7 \pm 0.1 \\
1.4 \pm 0.41 .9 \pm 0.3\end{array}$ \\
\hline
\end{tabular}

* Mean valueistandard error. All variances showed no significancy from the control values by statistical analysis.

$\mathrm{Zn}$ concentration was significant only with the level of $250 \mathrm{ppm} \mathrm{Zn}$. In contrast, the concentration of $\mathrm{Zn}$ in the pancreas with $50 \mathrm{ppm}$ dietary $\mathrm{Zn}$ was increased significantly by $62 \%$ over those of the basal control group. The concentration of $\mathrm{Zn}$ in the testes confirmed the same trend, but the magnitude was larger than in the pancreas. It is noteworthy that the testes contained the highest concentration of $\mathrm{Zn}$ among all organs tested at 10 days of life and contained the lowest concentration at 85 days. In the kidneys, $\mathrm{Zn}$ concentration was the same for the three groups receiving dietary $\mathrm{Zn}$ at 85 days. The three groups did not differ significantly from the control group. $\mathrm{Zn}$ concentration in the heart was not influenced by the dietary $\mathrm{Zn}$ levels at $20,30,40,50$ and 85 days of age. The levels of $\mathrm{Zn}$ in the heart of cockerels receiving dietary $\mathrm{Zn}$ was essentially the same as for cockerels fed the basal diet. No significant changes were noted in the concentration of $\mathrm{Zn}$ in the other tissues by increasing dietary $\mathrm{Zn}$ levels.

As the levels of diefary $\mathrm{Zn}$ were increased, a corresponding increase in Fe concentration in the liver was observed at 10 days of age but the differences between groups were insignificant. The dietary $\mathrm{Zn}$ levels appeared to be antagonistic to $\mathrm{Fe}$ concentration in the liver. The antagonistic effect was observed at 40,50 and 85 days of age but the data were statistically significant only at 50 days.

In the pancreas, there was an increase in the concentration of $\mathrm{Fe}$ with the increase in the dietary $\mathrm{Zn}$ levels at 10 days of age. Accompanying the increase in the dietary $\mathrm{Zn}$, smaller decreases were evident at $20,30,40,50$ 
and 85 days.

A slight increase in the Fe concentration was found in the testes by increasing the levels of dietary $\mathrm{Zn}$ at 10,20,30 and 40 days, while at 50 and 85 days, Fe concentration decreased as the levels of dietary $\mathrm{Zn}$ was increased. The decrease in Fe concentration was statistically significant with the levels of 1000 and $250 \mathrm{ppm}$ dietary $\mathrm{Zn}$ at 50 days.

At 10 days of age, variations between groups occurred in the Fe concen. t.ration in the kidneys. The cockerels fed 1000 ppm dietary $\mathrm{Zn}$ contained more Fe concentration in the kidneys than the cockerels fed the control diet, whereas the levels of 50 and $250 \mathrm{ppm} \mathrm{Zn}$ resulted in reduction in the Fe concentration as compared with the control group. These changes were not statistically significant. The antagonistic effect of dietary $\mathrm{Zn}$ in the kidneys was occurred from 20 days of age. At 50 and 85 days, the antagonistic effect was observed only with the level of $1000 \mathrm{ppm} \mathrm{Zn}$, while the levels of 250 and $50 \mathrm{ppm} \mathrm{Zn}$ at 50 days and the level of $50 \mathrm{ppm} \mathrm{Zn}$ at 85 days caused an increase over those of the control group, though statistical significance was not attained.

In the spleen and heart, there were an increase in Fe concentration with the increase in the dietary $\mathrm{Zn}$ levels at 10 days of age, but the only significant elevation was noted with the level of $1000 \mathrm{ppm} \mathrm{Zn.} \mathrm{A} \mathrm{trend} \mathrm{of} \mathrm{lower}$ concentration of Fe was observed in these organs as the levels of dietary $\mathrm{Zn}$ was increased at 30 and 50 days, but Fe concentration in the heart was significantly decreased with the levels of $1000 \mathrm{ppm} \mathrm{Zn}$ at 50 days of life.

None of the dietary treatments of $Z n$ had any significant effect on $\mathrm{Fe}$ concentration of the brain, breast muscle and leg muscle during all the experimental periods.

The $\mathrm{Cu}$ concentrations of the liver, kidneys, heart and brain were not affected by the addition of $\mathrm{Zn}$ to the diet and by duration of feeding. Whereas, the $\mathrm{Cu}$ concentration of the testes, pancreas, spleen, breast muscle and leg muscle was traces and there were undetectable changes with dietary $\mathrm{Zn}$ levels,

In order to prove more sufficiently the relationship between concentration of $\mathrm{Zn}$ or $\mathrm{Fe}$ in tissues and dietary $\mathrm{Zn}$, regression analyses on the $\mathrm{Zn}$ or $\mathrm{Fe}$ values in tissues versus the dietary $\mathrm{Zn}$ level and age were carried out. The present finding, where statistical significant relationships or trend were existed, are given in Tables 4, 5 and 6.

Analysis revealed highly significant $(p<0.01)$ positive linear regression of dietary $\mathrm{Zn}$ level on $\mathrm{Zn}$ concentration in the liver at 10,30 and 40 days of age and significant $(\mathrm{p}<0.05)$ at 20 and 50 days. But, it should be noted that the $\mathrm{Zn}$ concentration in the liver for the group receiving $50 \mathrm{ppm}$ dietary $\mathrm{Zn}$ was higher than the corresponding values for the group receiving $250 \mathrm{ppm}$ dietary $\mathrm{Zn}$ at 40 and 50 days (Table 1 ).

The linear regressions of dietary $\mathrm{Zn}$ level on $\mathrm{Zn}$ concentration in the pancreas were highly significant $(\mathrm{p}<0.01)$ at $10,20,30$ and 50 days of age and significant $(p<0.05)$ at 40 days. With the two higher levels of dietary $Z n$, there was a significant $(\mathrm{p}<0$. 01) negative linear regression of $\mathrm{Zn}$ concentration in the pancreas and duration of feeding (Table 5). 
'Table 4. Correlation coefficients between dietary $\mathrm{Zn}$ concentration and $\mathrm{Zn}$ concentration in selected organs,

\begin{tabular}{|c|c|c|c|c|c|c|c|c|c|c|}
\hline \multirow{2}{*}{$\begin{array}{l}\text { Period } \\
\text { (days) }\end{array}$} & & \multicolumn{9}{|c|}{ Correlation coefficients } \\
\hline & & Liver & Pancreas & Testes & Kidneys & Spleen & Heart & Brain & $\begin{array}{l}\text { Breast } \\
\text { muscle }\end{array}$ & $\begin{array}{c}\text { Leg } \\
\text { muscle }\end{array}$ \\
\hline 10 & $\mathrm{l}$ & $0.994^{1)}$ & $0.9861)$ & $0.937^{21}$ & $0.963^{11}$ & $0.83^{\prime} 5$ & -0.422 & 0.768 & $0.9113^{\prime}$ & 0.717 \\
\hline 20 & 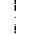 & $\left(0929^{3}\right)$ & 0.9791 & & 0.99211 & 0.9681 & 0.241 & 0.745 & 0.359 & $0.9333^{\prime}$ \\
\hline 30 & i & $0 \ldots .988^{11}$ & 0.9711 & 0.978333 & $0.980^{1}$ & 0.725 & $\left.0.887^{3}\right)$ & $0.954^{11}$ & 0.113 & 0.644 \\
\hline 40 & & $0.963 "$ & $0.8813^{\prime}$ & $0.944^{21}$ & 0.9283 & 0.763 & 0.449 & 0.293 & 0.787 & 0.701 \\
\hline 50 & & $0.8793^{\prime}$ & $0.973^{\prime}$ & 0.802 & 0.769 & -0.127 & -0.117 & 0.641 & -0.411 & -0.587 \\
\hline 85 & & 0.813 & 0.381 & 0.764 & 0.436 & -0.995 & $-0.8,24$ & 0.614 & 0.346 & 0.608 \\
\hline
\end{tabular}

$\left.{ }^{1)},{ }^{2)}, 3\right)$ Significant at $0.01,0.02$ and 0.05 level, respectively.

Table 5. Correlation coefficients between dietary $\mathrm{Zn}$ concentration and tissue $\mathrm{Zn}$ concentration during the experimental period.

\begin{tabular}{|c|c|c|c|c|c|c|c|c|c|}
\hline \multirow{2}{*}{$\begin{array}{l}\mathrm{Zn} \text { added } \\
\text { to th e } \\
\text { diet } \\
\text { (ppm) }\end{array}$} & \multirow[b]{2}{*}{ Liver } & \multirow[b]{2}{*}{ Pancreas } & \multirow[b]{2}{*}{ Testes } & \multicolumn{2}{|c|}{ Correlation } & coefficients & \multirow[b]{2}{*}{ Brain } & \multirow[b]{2}{*}{$\begin{array}{l}\text { Breast } \\
\text { muscle }\end{array}$} & \multirow[b]{2}{*}{$\begin{array}{c}\text { Leg } \\
\text { muscle }\end{array}$} \\
\hline & & & & Kidneys & Spleen & Heart & & & \\
\hline 0 & & & & & & & & & \\
\hline 50 & $-0.539-0.301$ & $\begin{array}{ll}-0.446 & -0.402\end{array}$ & $-0.9051^{\prime}-0.8781$ & $\begin{array}{ll}-0.439 & -0.177\end{array}$ & $-0.642 \quad-0.539$ & $-0.506-0.574$ & $-0.456-0.645$ & $-0.138-0.632$ & $-0.688 \quad-0.677$ \\
\hline 250 & -0.543 & -0.94511 & $-0.872^{11}$ & -0.371 & $-0.845^{22}$ & -0.657 & -0.313 & -0.658 & -0.736 \\
\hline 1000 & -0.596 & $-0.941 "$ & $-0.845^{22}$ & -0.686 & $-0.844^{21}$ & -0.667 & -0.689 & -0.688 & - 0. G38 \\
\hline
\end{tabular}

1), 2) Significant at 0.01 and 0.02 level, respectively.

Table 6. Correlation coefficients between dietarv Zn concentration and $\mathrm{Fe}$ concentration in selected organs.

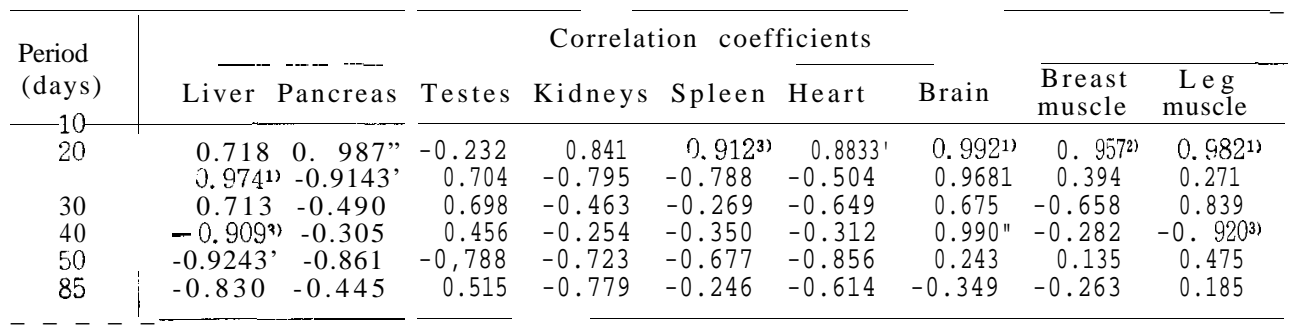

1), 2), 3) Significant at $0.01,0.02$ and 0.05 level, respectively.

Zn concentration in the testes showed positive linear relationship $(p<0.02)$ with the level of dietary $\mathrm{Zn}$ at 10 and 40 days of age and significant $(\mathrm{p}<0.05)$ at 20 days. It showed negative relationship between the duration of feeding and all dietary $\mathrm{Zn}$ levels(Table 5). $\mathrm{Zn}$ concentration in the kidneys increased with increasing dietary $\mathrm{Zn}$ levels. The response was highly significant $(\mathrm{p}<$ $0.01)$ at 10,20 and 30 days and significant $(\mathrm{p}<0.05)$ at 40 days of age. A positive linear regression between dietary $\mathrm{Zn}$ level and $\mathrm{Zn}$ concentration in the spleen was found to be highly significant $(p<0.01)$ at 20 days.

Significant $(p<0.01)$ linear increase in $\mathrm{Fe}$ concentration of the liver at 20 days and in the pancreas at 10 days occurred due to increasing $\mathrm{Zn}$ in the diet (Table 6). Significant $(p<0$. 05) linear decrease in Fe concentration in the liv- 
er occurred at 40 and 50 days of age when the level of $\mathrm{Zn}$ in the diet increased. The same trend occurred at 85 days but was not significant. In the pancreas, the only significant $(p<0.05)$ negative relationship between the levels of dietary $\mathrm{Zn}$ and the concentration of $\mathrm{Fe}$ was noted at 20 days of age.

\section{DISCUSSION}

In the present study, the apparent linearity of the relationship between $\mathrm{Zn}$ concentration in the liver, pancreas, testes and kidneys and the levels of dietary $\mathrm{Zn}$ supplementation indicated that additional $\mathrm{Zn}$ would have accumulated with increasing the levels of $\mathrm{Zn}$ in the diet. Whereas, the lack of significant linearity in all tissues at 85 days of life suggested that after long term feeding, the homeostatic mechanism can prevent the tissue content from remaining at the initially increased level. Stake et al. (1975) have concluded, however, that no homeostatic adaptation was detected in the liver, pancreas and kidneys of calves during 21 days period by $600 \mathrm{ppm}$ dietary $\mathrm{Zn}$. The same diet did not materially affect the $\mathrm{Zn}$ content of the liver and kidneys in rats suggesting that the homeostatic mechanism of $\mathrm{Zn}$ are much more effective in rats (Ansari et al., 1976). From the result of the present study it is evident that fowl is similar to rats rather than to calves in their response to dietary $\mathrm{Zn}$ Supplementation.

There are several factors which may have contributed to the contradictory results in the literature. One of these factors to be considered is age of animals. In this context the finding of Miller and Cragle (1965) that $\mathrm{Zn}$ absorption decreases as cattle get mature and the accumulation of $\mathrm{Zn}$ is probably related to absorption. In the present study, examination of the relationship between dietary $\mathrm{Zn}$ and tissue $\mathrm{Zn}$ at the duration of feeding suggested that the pancreas and testes showed negative correlation. This indicated that there was no tendency for the cockerel to store $\mathrm{Zn}$ in the pancreas with the two highest levels and in the testes with all dietary $\mathrm{Zn}$ levels. These findings are in agreement with the study of Kincaid et al. (1976), who reported Zn homeostatic control mechanism protected the tissue, for at least limited periods of time, against increased $\mathrm{Zn}$ in tissues from dietary $\mathrm{Zn}$ up to $1200 \mathrm{ppm}$ in the chick. In contrast, $\mathrm{Zn}$ concentration was unaffected in certain other tissues especially heart, brain and muscle indicating complete homeostasis (Stake et al., 1975).

The concentration of $\mathrm{Fe}$ in the liver, testes, kidneys, spleen and heart also tended to be influenced by $\mathrm{Zn}$ intake. In the fact, $\mathrm{Fe}$ concentration in these organs tended to be lowest when the dietary $\mathrm{Zn}$ was highest, suggesting noteworthy relationship between $\mathrm{Zn}$ and $\mathrm{Fe}$. The decrease in $\mathrm{Fe}$ concentration in the present study with high dietary $\mathrm{Zn}$ may seem at variance with the result of Ott et al. (1966) who found an increase in $\mathrm{Fe}$ of the liver of cattle fed high levels of dietary $\mathrm{Zn}$ for 10 weeks periods. In rats, Cox and Harris (1960) reported a high inverse correlation between Fe concentration in the liver and kidneys and dietary $\mathrm{Zn}$ levels of rat fed high $\mathrm{Zn}$ diet. This relationship was detected after 7 days, whereas in the present study the antag. 
onistic effect was detected from the 40th day of age. The effect on fowl would appear to be rather similar to that in rat than that in cattle but fowl appear to be somewhat more resistant to the antagonistic effect. From the result of this study, it is evident that the $50 \mathrm{ppm} \mathrm{Zn}$ added to the diet induced an increase in $\mathrm{Zn}$ concentration in the liver, kidneys, pancreas and spleen, but could not induce any reduction in $\mathrm{Fe}$ concentration. This result is in agreement with the proposal that $\mathrm{Zn}$ level in these organs must attain a critical level before interfering with the $\mathrm{Fe}$ absorption. In view of this proposal, the $\mathrm{Zn}$ level in the liver, spleen and heart with high $\mathrm{Zn}$ intake did not attain a critical level to affect $\mathrm{Fe}$ content until 40 to 50 days in the present study.

Cox and Harris (1960) have reported that rats fed high levels of dietary $\mathrm{Zn}$ exhibited an early loss of the liver $\mathrm{Fe}$, and after a relatively long period of time also exhibited a reduction in liver $\mathrm{Cu}$. The data suggested that the reduction of liver $\mathrm{Cu}$ was a result of reduced liver $\mathrm{Fe}$ rather than an effect of liver $\mathrm{Zn}$. In contrast, in the present study, the results showed that $\mathrm{Cu}$ concentration in the liver and heart was not changed in the fowl by any dietary treatment throughout the experimental period. In support of the present finding Johnson et al. (1962) reported in the fowl that the concentration of $\mathrm{Cu}$ in the liver was not affected by several graded level of dietary $\mathrm{Zn}$, up to $4000 \mathrm{ppm} \mathrm{Zn}$. Another possible explanation to account is that the level of $\mathrm{Fe}$ was not reduced to the critical level to affect $\mathrm{Cu}$ metabolism (Cox and Harris, 1962).

\section{ACKNOWLEDGMENT}

The authors wish to express appreciation to prof. K. Wada, Laboratory of Soil Science, Kyushu University for the use of atomic absorption spectrophotometer.

\section{REFERENCES}

Ansari, M. S., W. J. Miller, M. W. Neathery, J. W. Lassiter, R. P. Gentry and R. L. Kincaid 1976 Zinc metabolism and homeostasis in rats fed a wide range of high dietary Zn levels. Proc.Soc. Exp. Biol. Med., 152: 192-194

Cox, D. H. and D. L. Harris 1960 Effect of excess dietary zinc on iron and copper in the rat. J.Nutr., 70: 514-521,

Cox, D. H. and D. L. Harris 1962 Reduction of liver xanthine oxidase activity and iron storage proteins in rats fed excess'zinc. J.Nutr., 78: 415-419

Eltohamy, M. M., H. Takahara and M. Okamoto 1979 Effects of dietary Zn levels on the histological changes produced in White Leghorn cockerels. J. Fuc. Agr., Kyushu Univ., 24: $11-20$

Johnson, D. J. R., A. L. Mehring, Jr.. F. X. Savino and H. W. Titus 1962 The tolerance of growing chickens for dietary zinc. Poult.Sci.,41:311-317

Kincaid, R. L., W. J. Miller, L. S. Jensen, D. L. Hampton, M. W. Neathery and R. P. Gentry 1976 Effect of high amounts of dietary zinc and age upon tissue zinc in young chicks. Poult. Sci.. 55: 1954-1957

Miller, W. J., D. M. Blackmon, R. P. Gentry and F. M. Pate 1970 Effects of high but non- 
toxic levels of zinc in practical diets on ${ }^{65} \mathrm{Zn}$ and zinc metabolism in Holstein calves. J.Nufr., $100: 893-902$

Miller, J. K. and R. G. Cragle 1965 Gastrointestinal sites of absorption and endogenous secretion of $\mathrm{Zn}$ in dairy cattle. J. Dairy Sci., 48: 370-374

Ott, E. A., W. H. Smith, R. B. Harrington. H. E. Parker and W. M. Beeson 1966 Zinc toxicity in ruminants 3. Physiological changes in tissues of beef cattle. J. Anim. Sci., 25: 419-423

Settlemire, C. T. and G. Matrone 1976 In vivo interference of zinc with ferritin iron in the rat. J. Nutr., 92: 153-158

Smith, S. E. and E. J. Larson 1946 Zinc toxicity in rats. Antagonistic effects of copper and liver. J.Biol. Chem., 163: 29-31

Snedecor. G. W. 1956 Statistical Methods. 5th ed. Iowa State Univ. Press, Ames., Iowa.

Stake, P. E., W. J. Miller and R. P. Gentry 1973 Zinc metabolism and homeostasis in ruminants as affected by dietary energy intake and growth rate. Proc. Soc. Exp. Biol. Med., 142: 494-496

Stake, P.E., W. J. Miller, R. P. Gentry and M. W. Neathery 1975 Zinc metabolism adaptation in calves fed a high but nontoxic zinc level for varying time periods. J. Anim. Sci., 40: 132-137

Van Campen, D. R. and R. U. Scalfe 1967 Zinc interference with copper absorption in rats. J. Nutr., 91: 473-476 